\title{
Limited Amendment of 1945 Basic Constitution and The Return of Main State Guidelines
}

\author{
${ }^{1}$ SUDI FAHMI, ${ }^{2}$ ADRIAN FARIDHI \\ 1,2 Faculty of Law Lancang Kuning University, Jalan Yos Sudarso KM 8 Rumbai Pekanbaru, Indonesia \\ correspondence author: ${ }^{1}$ adrian@unilak.ac.id
}

\begin{abstract}
This study focuses on the consequence of discourse for bringing back the Main State Guidelines (GBHN) in the administration structure of Indonesian Republic. The GBHN has been considered a solution for the insustainability of Indonesian development, despite the fact that there have been the constitutions of National Development Planning System (SPPN), Long-Term Development Plan (RPJP), Medium-Term Development Plan (RPJM), and Annual Development Plan. The research method used is the study of normative law. The results obtained from the study are to bring back the GBHN, to require the amendment of Basic Constitution of 1945, to harmonize the statutory regulations such as the material test and juridical review of People's Consultative Assembly's decree regulating the GBHN, adjustment to the president's liability in implementing the GBHN, and evaluation towards the National Development Planning System (SPPN) which so far have been implemented to produce the efficient development planning. This paper concludes that the GBHN presence will lead to the legal consequences of state administration and the rearrangement of the state administration itself.
\end{abstract}

Keywords: main state guidelines (GBHN), amendment, developmental planning

\section{Introduction}

Indonesian Republic Constitution in the form of Basic Constitution 1945 has been revised four times in the People's Consultative Assembly annual court since 1999 to 2002. The Basic Constitution after the amendment has given a new face for the arrangement of Indonesian state administration. One of the revisions made after the change of Basic Constitution is the absence of People Consultative Assembly's authority to arrange and establish the Main State Guidelines (GBHN) as it was previously arranged in the Body of Basic Constitution, particularly in Article 3 explaining People Consultative Assembly's authority to revise and establish the Basic Constitution and to form the Main State Guidelines (GBHN) as the Guidelines for the national development.

Indonesia as the Five-Principle based state of law built upon the values of the Five Principles (Simamora, 2014:560) is interpreted in such a way as mandated by the Five Principles. Meanwhile, the Basic Constitution of 1945 adheres to the active and dynamic state of law concept (Ridlwan, 2012:150). This combination has given Indonesia different characteristics compared to other states. The revision of Basic Constitution 1945 may become inevitable for the sake of ameliorating the state administration and order. One of the discourses that become the discussion topic, scientific debate, and a national issue in the past five years in higher education and national-scale discussions is to bring back the concept and mechanism which were previously regulated in the GBHN and the state administration structure. Bringing back the GBHN will lead to the administrative and legal consequences and also affect the political constellation for the ability to reamend Basic Constitution 1945.

The status of People's Consultative Assembly before the change was equal to the highest state organization with unlimited power (superpower) (Mulyani, 2016: 95). This can be seen in the People's Consultative

Received: 2020-03-28, Revised: 2020-05-05, Accepted: 2020-06-03. 
Assembly's authority to revise and establish the constitution and to elect and inaugurate the president and vice president. In other words, the roles of People's Consultative Assembly in running the sovereignty by upholding the values of democracy remain important. However, the status of People's Consultative Assembly after the Basic Constitution revision is equal to other state organizations and its authority is restricted by the Basic Constitution (Kusumaningtyas, 2018:6). The constitutional position of People's Consultative Assembly is equal to the other state organizations such as People's Representative Council/ House of Representative (DPR), Regional Representative Council (DPD), and the presidential organizations as a result of General Election process. The absence of GBHN has made People's Consultative Assembly lose its existence as the highest state organization (Sofia L.Rohi, 2013:88). People's Consultative Assembly has no longer become a joint session when People's Representative Council and Regional Representative Council merge. Therefore, some experts have been questioning the existence of People's Consultative Assembly's duty as merely revising and establishing the Basic Constitution.

The declaration of people's will in terms of state administration is outlined in the main guidelines (GBHN). The GBHN in the wheels of government administration can be used to guide the success and accomplishments of the ruling government's direction and purpose (and correct the mistakes if there are any) (Simamora, 2016:3432). This has been the government idea to bring back the GBHN as one of People's Consultative Assembly's authorities. Such circumstances will certainly encounter some clashes in the current stable and prevailing state administration arrangement. If the GBHN are brought back in the state administration of Indonesian Republic, the consequence will be the rearrangement of the state institutional structures and functions which have been outlined in the post-amendment Basic Constitution 1945.

People's Consultative Assembly will exist if it has a position in the state administration structure. People should be given authorities and rights to assess state organizations' performance and legal products owned by the institutions implementing Basic Constitutions, and also to remake the GBHN (Asmara, 2015: 369). It is an emphasized discourse on the reborn of GBHN.
The arrangement of the state structures becomes a compulsory and a necessity in order to avoid clashes of authorities among state institutions. The idea to bring back the GBHN in Indonesian state administration system is based on the following backgrounds: first, the absence of sustainability in the development implementation in which every elected president may propose some national development programs of their own; second, the coverage of the National Long Term Development Plan (RPJPN) and Medium Term Development Plan (RPJMN) is outlined in the norms which merely include executive power; third, the absence of GBHN will lead to the appointment of the president as the party who determines his own political platform of national development; fourth, the development policies issued by both the central and regional government are asynchronous (Indra, Mexsasai \& Adhayanto, 2018: 98). Public awareness and understanding of regulations and ethics realized through public participation in the transparency of various local government policies will accelerate the realization of good and clean governance (Rachmiatie et al., 2015).

The state administration and legal problems occurring due to the idea of bringing back People's Consultative Assembly's authorities to arrange the GBHN will be the study of state administration. This study analyzes ius constituendum when GBHN becomes part of the agenda in the fifth revision of Basic Constitution. Therefore, this study is "Limited Amendment Of 1945 Basic Constitution And The Return Of Main State Guidelines". The idea of bringing back the GBHN is the matter of rearranging the Indonesian state administration which has been running for seventeen years. This study aims to find out the possible state administration problems occurring as a result of bringing back the GBHN in the fifth Basic Constitution amendment discourse.

\section{Research Methodology}

The method used in this study is normative law research. It is implemented in both constitutional and conceptual approaches. These two are useful in analyzing the represence of GBHN in the Indonesian state administration structure along with its accompanying state administration and legal problems.

Secondary data used as data resources 
consists of journals and books that facilitate the researcher in explaining the study being investigated. Data collection technique is done by gathering the literatures that explain the correlation of problems. The normative legal data analysis is done qualitatively and subsequently outlined in descriptive sentences and language by elaborating the currentlyinvestigated state administration and legal problems systematically and thoroughly. Data conclusion technique used is inductive method, which is the conclusion drawn from specific to general statement.

\section{Results and Discussion}

The idea to bring back the GBHN in Indonesian state administration has been taking place for a few years. This can be seen in the studies conducted either by the People's Consultative Assembly assessment body or by some universities discussing the functions and authorities of People's Consultative Assembly such as issuing People's Consultative Assembly's Decree and reforming the Main State Guidelines (GBHN). Those are parts of People's Consultative Assembly's authorities in Indonesian state administration structure after the removal of People's Consultative Assembly's authorities to form the GBHN in the post-revision Basic Constitution 1945. The researcher located some state administration-related problems in this study outlined below:

\section{The Need for Amendment of Basic Constitution 1945}

Constitutional or Basic Constitution Change according to CF Strong should be: first, done by the legislative with some restriction; second, conducted by the society through referendum; third, done by united countries in some federal states; and fourth, done by the state organizations which are specific to change or through convention (Ilyas, 2013:54). The Main State Guidelines (GBHN) in the 1945 Basic Constitution used to exist in the national and state traditions. However, it was removed from the Main Body of Basic Constitution after the amendment. The amendment is possible if we refer to article 37 section 1 to 5 of the 1945 Basic Constitution stating that the proposal of amendment needs the presence of two-third of People's Consultative Assembly's members and fifty percent plus one to make the decision for revision. The articles outlined are made into written form and accompanied by the background and reasons of revision. There is only thing that unchangeable, that is the Unitary State form. Basic Constitution does not forbid any parties to bring back the GBHN in Indonesian state administration system. It gives a way for the proposers of revision to rearrange People's Consultative Assembly's authorities (Saraswati, 2017:235) which was once missing from the Basic Constitution (Setiadi, 2016:46) in order to be (re)assigned as the People's Consultative Assembly's authority.

Based on the requirements explained in the Basic Constitution, the revision system of Basic Constitution in Indonesian Republic State is categorized as a rigid one due to its difficulties and loads to meet the requirements and criteria of the revision procedures. However, it is impossible to revise as long as people are willing to have the revision through their representatives in People's Consultative Assembly.

The fulfillment of requirements to amend Basic Constitution 1945 based on Article 37 should have great support both in terms of amendment proposal and the society's will to approve the amended points. It takes the vote requirement of fifty percent plus one representing more than a half of People's Consultative Assembly members to approve the amendment results as the majority approval and agreement.

2019 General Election has been completed with the appointment of Ir. H. Joko Widodo as the President and Prof. Dr. (H.C.) K.H. Ma'ruf Amin as the Vice President for the administration period of 2019 to 2024, and People Representative Council and Regional Representative Council for the service period of 2019 to 2024. People's Consultative Assembly comprises the membership of People's Representative Council and Regional Representative Council. There are 711 members of People's Consultative Assembly for 2019 to 2024 periods consisting of 575 members of People's Representative Council and 136 members of Regional Representative Council. People's Consultative Assembly membership comes from 9 political parties and 1 element of Regional Representative Council (representing 34 provinces in Indonesia). The great number of membership may create the councils' problems to attain a political support for the sake of succeeding the fifth Basic Constitution 1945 amendment agenda. The initial requirement of revision among some phases of Basic Constitution revision 
is the forum of 237 members of People's Consultative Assembly in the submission of proposal. Besides, it should be attended by 474 members of People's Consultative Assembly in the Plenary Meeting of Basic Constitution revision and should at least be approved by 357 members of People's Consultative Assembly during the decision making of the Plenary Meeting. The aforementioned requirements and decree are categorized as rigid and irreversible, particularly to change the Basic Constitution.

The post-reformation Basic Constitution amendment starting in 1999 to 2002 has assigned some consensus in the Basic Constitution revision agenda as follows: first, there is no revision towards the preamble to 1945 Basic Constitution; second, the unitary state form is maintained; third, the strengthening of presidential government system is emphasized; fourth, the explanation of Basic Constitution is deleted; and fifth, the Basic Constitution revision should be conducted with "addendum" system (Sekretariat Jenderal MPR, 2017:18). On that basis, the preamble to Basic Constitution is not revised at all. In addition, there is an emphasis that the unitary state form is irreversible as stated in Article 37 Section (5), that the presidential strengthening through direct presidential election and Basic Constitution Explanation are omitted from the part of Basic Constitution.

Basic Constitution revision aims at implementing the presidential purification system conducted by changing the direct presidential election which is not through the representatives of People's Consultative Assembly. The president service period is limited. The mechanism of dismissing the president and the arrangement of representative organizations are itemized and emphasized (Isra, 2013:405). These are illustrated in the articles with revision in the Basic Constitution.

The submission of proposals to amend the 1945 Basic Constitution for the fifth time needs the agreement from both the circle of People Consultative Assembly and the society as the true owner of sovereignty. This is essential in order to avoid the randomness in the amendment and the obscurity of the initial purpose in amending 1945 Basic Constitution itself. Besides, it eludes the overlapping authorities outlined in Basic Constitution 1945. The Basic Constitution 1945 revision was once proposed in the
People's Consultative Assembly members' service period of 2004 to 2009, but failed during the support gathering stage to propose the amendment. The obstacles they encountered were the difficulties in meeting the requirements determined by the1945 Basic Constitution. The revision draft proposed by People's Consultative Assembly's members according to Regional Representative Council's elements is not easy and nearly impossible due to the procedures of Basic Constitution revision that are too rigid. In addition, the revision does not have the majority power to support the change, so that the forum finds it is hard to implement (Hajri \& Rahdiansyah, 2017:562). Referring to the political condition after the General Election Commissions of Indonesian Republic announcing the winners of Presidential Election and Legislative Election in 2019, the thoughts to revise the Basic Constitution, particularly to present the GBHN are highly possible since some political elites show their intention and support to bring back the GBHN through the fifth stage of Basic Constitution revision.

Restriction made by the constitution compilers may refer to one event to another (Wheare, 1996:13). The regulation of GBHN is accompanied by some restriction regulated in the Basic Constitution 1945. The existence and presence of GBHN cannot be separated from the true nature and meaning of People's Consultative Assembly as the holder of society's sovereignty. This can be studied in the once-prevailing People's Consultative Assembly's Decree related to the GBHN, starting from the Provisional People's Consultative Assembly's Resolution Number 1/MPRS/1960 regarding the Political Manifesto of Indonesian Republic as the Main State Guidelines issued in the administration era of President Soekarno or the so-called Old Order (Indra, Mexsasai \& Adhayanto, 2018:100).

General Election and Regional Head Election are the realization of people's sovereignty as regulated in the Basic Constitution. The state protection in maintaining the human right of citizens is conducted fairly and democratically (Faridhi, 2018:87). Therefore, the realization of people's sovereignty is no longer the monopoly of People's Consultative Assembly, but shared among executive and legislative institutions; while the succession of Regional Heads can reflect the values of democracy as outlined in the general election system (Faridhi, 2019:245). People's sovereignty 
no longer becomes the monopoly of People's Consultative Assembly, but is represented in the state administration practices of the executive power both in the local (regional) level and the national (central) level.

Based on the history of Indonesian state administration, the revision of constitution in the reformation era was the effects of great-scale demonstration involving the majority of the national components to take down President Soeharto. The conflicts caused by the financial and economic crisis in 1997 had turned Indonesia into the verge of national disintegration and chaos. In the initial era of reformation, the desire and insistence emerged from people to criticize Indonesia as a state not having enough efforts to maintain and uphold democracy, the respect towards Human Rights, and the empowerment of people who have been ruled by the authoritarian regime (Azwar, 2017:9). However, the demand for revising the Basic Constitution 1945 at the moment was not the same as what happened in 1997 in terms of political and economic condition, but more as a thought considering the omission of GBHN as a mistake or a fallacy. Therefore, there is some insustainability between the former and current president. The aforementioned issues become one of the backgrounds for the fifth 1945 Basic Constitution amendment to arrange the development planning in Indonesia in sustainable and integrated way from time to time, from the national to the regional levels.

The existence of GBHN, which is interpreted as it was in the past, is contradictory with the other recommendations proposed by People's Consultative Assembly that intend to strengthen the presidential government system. One of the reasons in omitting the GBHN during the previous amendment of 1945 Basic Constitution was to erase the parliamentary character attached to Indonesian presidential system (Indra, Mexsasai \& Adhayanto, 2018:103). However, in the implementation, the omission of GBHN has become one of the unplanned factors in the national development and is expected to be sustainable in the ruling government regime. The leadership may change but the development sustainability must be continued and put into synergy (Rendy, 2017:30). The development planning must be designed in integrated and visionary way in order to predict possibilities and targets to be achieved by the nation for the sake of accomplishing national and state future goals.
Basic Constitution revision is a logical step to accommodate the GBHN as the People's Consultative Assembly's authorities, apart from what is given by the Basic Constitution. However, it takes a great political support from People's Consultative Assembly to put the revision discourse into actions.

\section{Harmonization in Laws and Regula- tions}

Steps to amend the Basic Constitution are the initial stage of bringing the GBHN back into Indonesian state administration structure. The revision of Basic Constitution will give legal implications towards the running legislation system, in which the laws and regulations are organized in levels and orders, which is today known as the hierarchy of laws and regulations. Hierarchy of Laws and Regulations according to the Law Number 12 of 2011 regarding the Formation of Legislation in article 7 section 1 consists of: first, 1945 Basic Constitution; second, Decree of People's Consultative Assembly; third, Law/ Government Regulation as the Replacement of the Laws; fourth, Government Regulation; fifth, President Regulation; sixth, Regional Regulation of Provincial Level; and seventh, Regional Regulation of Regency/Municipality Levels.

The leveling of legal norm regulation leads to consequences towards the enforcement of legal principles "/ex superior derogat legi inferior", in which the superior rules may put aside the inferior ones. The provisions of regulations hierarchy are universal, meaning that when the GBHN are represented in the form of People's Consultative Assembly's Decree, there is a chance that Basic Constitution will contradict the Decree. This kind of condition should be specifically regulated in the Basic Constitution, since there has not been a legislative mechanism in Indonesia to organize a completion if any disputes are found. Therefore, the potential of the absence of law can be avoided when the GBHN is established. It turns out that the Main State Guidelines (GBHN) is in contradiction with the Basic Constitution. The revision of 1945 Basic Constitution must be accompanied by the addition of the right to review/judicial review mechanism (both material and formal) towards the decree of People's Consultative Assembly that is in contradiction with the Basic Constitution. This can be a legal solution towards the absence of law and legal products issued by People's Consultative Assembly 
(which do not exist at the moment).

The right to review is also called toetsingsrecht which consists of two words: toetsing and recht. The word 'review' in Dutch is called toetsing, and the word recht means law and right. The legal system of one country is different than the others. As a result, it brings different consequences to the institutions given the right to review the laws and regulations (Fatmawati, 2004:XI). Besides toetsing recht, there are also other terms in the concept of review called judicial review, legislative review and executive review. These three terms have different meanings and tend to stand alone. For instance, juridical review can be interpreted as the right or authority to review given to judicial institutions towards legislative, executive, and judicative legal products. Legislative review is the right or authority to review legislative legal products such as constitutions or regional regulations done independently by the constitution-maker institution or the legislative institutions. Executive review is the right and authority to review given to executive or government institutions (Simatupang, 2019:226). Reviews can be categorized according to the objects being tested.

Based on the Constitutional Court Decision Number 137/PUUXIII/2015, revoking and canceling the Central Government and Governor's authorities towards local regulation both in regency and municipality levels done is by the Ministry of Internal Affairs. Based on the legal considerations, the decision consists of: first, the Basic Constitution guarantees the implementation of autonomy in the form of local government's legal products. The formation of local regulation is a regional legislation product as the realization of people's sovereignty in the regional level; second, upholding the legal state concept so that the justice institutions are considered having the competency to assess the legislation products (Firdaus, 2019:395). The Constitutional Court Decision on the cancellation of regional regulation is one of the judicial-review products in the arrangement and harmonization of laws and regulations, since before the Constitutional Court Decision was issued; the Ministry of Internal Affairs has cancelled more than 3500 regional regulations in the provincial, regency, and municipality levels.

Judicial institution can assess regulations based on the Basic Constitution. Thus, there is a separation of a higher regulation review by judicial institution that is divided into constitutionality review and a review by justice institutions towards constitutionality. The mechanism of constitutionality review is conducted by the legislative (People's Consultative Assembly) or by the justice institution known as constitutional review (Faridhi, 2017:191-192). Nowadays, the authorities of judicial review outlined in the Basic Constitution are only given to the Supreme Court and Constitutional Court.

The mechanism of review by the justice institution in Indonesia is conducted by Supreme Court and Constitutional Court. They have the authorities to review regulations differentiated based on the levels of norms being reviewed. Article 24 A section 1 of 1945 Basic Constitution states that: Supreme Court has the authority to adjudicate at the cassation level, examine the statutory regulations under the law towards the other law, and has other authorities granted by the constitution. This article set a basis for the Supreme Court to perform judicial review towards the regulation under the constitution. Related to judicial review by Supreme Court, article 24 C section 1 states that: Supreme Court has an authority to adjudicate in the first and last levels, the decision of which is final to examine the relevance of the constitution towards the Basic Constitution, to make a decision in regards to the disputes of authority among state institutions whose authorities are given by the Basic Constitution, to make a decision in regards to the dispersion of political parties, and to make a decision in regards to the disputes on general election results (Faridhi, 2017:186). This provision explains that there has not been any mechanism to review People's Consultative Assembly's Decree towards the Basic Constitutions as elaborated before.

The examination of legislation is a formal review related to the procedures and authorities of formation of legislation. Meanwhile, the material review is an assessment of whether the materials (content) of a regulation is contradictory or non-contradictory with the higher-level provisions and which authorities issuing the regulations (Fatmawati, 2004:6). The existence of People's Consultative Assembly's Decree in regards to the GBHN will be the material and objects of formal review objects towards 1945 Basic Constitution, particularly when the GBHN are formed and use the Decree of People's Consultative Assembly as the legal protection. The issues to merge are the state constitutions 
that authorized to examine the Decree of People's Consultative Assembly which are in contradictory with Basic Constitution. Referring to the state administration routines as regulated in the Basic Constitution, the implementation of constitution review towards Basic 1945 Constitution is implemented by the Constitutional Court.

If an authority is given to a state organization, the Constitutional Court as the guard of an institution will be given an additional authority based on Basic Constitution to examine the Decrees of People's Consultative Assembly towards the Basic Constitution. This is called Ius Constituendum as the consequence of the GBHN's presence in the state administration system of Indonesian Republic. By giving the examination authority only to the Constitutional Court, the examination problems can be solved and must be accompanied by the steps to amend the 1945 Basic Constitution, in particular, article $24 \mathrm{C}$.

The Decrees of People's Consultative Assembly was once missing in the hierarchy of laws and regulations according to article 7 sections 1 and 2 in the Law Number 10 of 2004 on the Formation of Laws and Regulations. Moreover, according to the Revision of Law Number 12 of 2011 issued through the Law Number 15 of 2019, there has not been a mechanism of examining the Decrees of People's Consultative Assembly towards the Basic Constitution. The authorities of People's Consultative Assembly to issue or publish a proper regulation (Rageling) in the form of People's Consultative Assembly's Decrees, which was practiced by People's Consultative Assembly before the Basic Constitution was revised, have left nothing but the authorities of People's Consultative Assembly to issue a legal product in the form of Decision (Beschikking). Since its issuance, the Decree of People's Consultative Assembly Number I/ MPR/2003 is the last legal product in the form of Decree issued by People's Consultative Assembly since 2003 until today.

\section{The Implication of GBHN towards President's Liability}

The revision of Basic Constitution has brought a fundamental change in the political mechanism, Presidential Election, and the Indonesian state administration practices. Those changes also bring consequences of revision in terms of president's liability, in which the liability is influenced by the administration system (Hendra, 2016:20). Indonesia as the country that adhere the presidential system has its characteristics. Before the revision of Basic Constitution was made, People's Consultative Assembly had an authority to elect President and Vice President (Sukma, 2017:287). However, after the revision, the procedures of president and vice president election are conducted directly through the people's vote. These circumstances bring some consequences towards the accountability reports of presidency institutions. In the Basic Constitution prior amendment, the President should be responsible to the People's Consultative Assembly in terms of conveying the liability report in the People's Consultative Assembly Plenary Court since the president is the mandatory of People's Consultative Assembly. However, after the Basic Constitution Amendment, the President no longer had to convey the liability report to the People's Consultative Assembly as stated in article 6 section 2 of the Basic Constitution prior amendment stating that People's Consultative Assembly is given an authority to elect president and vice president. It is different from the post-amendment Basic Constitution provisions stating that the sovereign people deserve to make options in regards to the president and vice president in general election. The president is not politically responsible to political organizations since the president election process is conducted through a direct vote by people (Hudi, 2018:189). Hence, the president is responsible to people who had voted for him.

The mechanism of president and vice president candidacy can only be proposed by political parties or a group of political parties. The mechanism of president and vice president election is regulated distinctly in the Basic Constitution. Thus, president and vice president are not elected by People's Consultative Assembly. In other words, the positions of president and People's Consultative Assembly institution are equal. Therefore, the president's liability procedure is no longer relevant in the post-amendment state administration context.

The prior-amendment Basic Constitution had not regulated distinctly the separation and division of power vertically and that the equality and balance principles are not primary (Nazriyah, 2017:45). However, after the 1945 Basic Constitution post-amendment was launched, all state organizations followed check-and-balance principles in the form of 
division of power from Montesquieu into the fields of executive, legislative, and judicative which are mutually equal and control each other. In addition, the power is restricted, regulated, and controlled so that the misuse can be prevented (Asshiddiqie, 2010:61). Basic Constitution revision has made People's Consultative Assembly reduce its power in electing the president (Yusdar, 2016:163). People's Consultative Assembly's power has decreased by itself as the consequence of presidential system enforcement.

The principles of power division cannot be separated from check-and-balance provisions in a sense that executive, legislative, and judicative can find their balance and mutually strengthen each other (Sunarto, 2016:159160). Referring to the post-amendment Basic Constitution, Indonesia complies with check-and-balance system illustrated in the ideas of Basic Constitution revision for the basic perfection of the state coordination by obeying the division of power based on the democratic values, so that the power holders and people can mutually supervise and balance each other in a transparent and strict way (Zoelva, 2011:64). The legislative supervision towards the executive in running the administration becomes an essential thing (Zulfan, 2017:154). This is because the unlimited, unrestricted, and unsupervised power will lead to deviation. The countries having written constitution have agreed that such power must be restricted.

People's Consultative Assembly has a huge power so that the system of mutually controlling and supervising the other states' organizations related to People's Consultative Assembly cannot be done. This is because People's Consultative Assembly is the party that controls, manages, supervises, and determines the fate of state organizations apart from itself. The potential policies or People's Consultative Assembly's Decisions which are contradictory with the Basic Constitution, Human Rights, and Democracy cannot be prevented, countered, or cancelled by other state organizations (Rohmat, 2016:185). This is when People's Consultative Assembly acts as the highest institution of the nation.

Article $7 \mathrm{~A}$ of the post-amendment of 1945 Basic Constitution states that "President and/or Vice President can be dismissed during his service period by People's Consultative Assembly based on the People's Representative Council's proposal, particularly when he is proven to commit some legal violation such as traitor to the state, corruption, bribery, other heavy criminal acts, or contemptible deeds; also when he is proven for no longer meeting the requirements of being a President and/or Vice President."

Impeachment or dethroning of president is an effort from the legislative to criminate the government or civil officials as the form of supervision towards the executive by the legislative with the final decision of position dismissal and prohibition of holding certain positions (Marpaung, 2015:124). The society will elect the public officials to run their duties and responsibilities. Therefore, a controlling function of a parliament towards the executive is necessary (Kristiyanto, 2013:335). People's Representative Council runs its controlling functions towards violation of law, in which impeachment is the mechanism of the controlling function (Fauzan, 2011:75). The need of mechanism for dethroning the president is an effect of a state administration event when President Abdurrahman Wahid was dismissed during his service period through People's Consultative Assembly's mechanism.

The government runs their vision and mission during the campaign of president and vice president candidates and the general election. At the same time, the president should follow the direction of policies regulated in the GBHN. There are always the possibilities for the incompatibility between the government policies and the GBHN made by People's Consultative Assembly which will be the state administration related problems in the future. Unfortunately, there has not been a legislation mechanism regulating this matter. The amendment 1945 of Basic Constitution must regulate the mechanism of president's liability towards the implementation of the GBHN when the president does not run the political direction and principles according to the GBHN.

\section{Development Planning of Indonesian Republic State}

Based on the post-reformation general election results, People's Consultative Assembly issued the Decree of People's Consultative Assembly (TAP MPR) Number $4 \mathrm{IV} / \mathrm{MPR} / 1999$ in regards to the GBHN of 1999 to 2004. The Decree was the last legal product regulating the GBHN that is different from the one in President Soeharto's era. 
The difference lies in the main objectives or the state guidelines in the form of national development with the state administration (Subkhan, 2014:137-138). This kind of difference occurred because of the conditions and background which underlie the formation of the GBHN. The post-reformation GBHN aims to improve the state administration which has recently tended to be authoritarian and centralistic.

According to Yessy Anggraini, the lack of socialization of the existence of National Development Planning System (SPPN), Longterm Development Plan (RPJP) and Mediumterm Development Plan (RPJM) has led the discourse of bringing back the GBHN to arise (Anggraini et al., 2015:88). Yessy Anggaraini illustrates that the development in Indonesia has been regulated in various instruments such as National Development Planning System (SPPN), Long-term Development Plan (RPJP), and Medium-term Development Plan (RPJM). The development carried out by several Presidents after the 1945 Basic Constitution amendment has been running well. However, it seems as if there is no sustainability in the development. The lack of integration of the development is the background for the birth of the GBHN.

The National Long-term Development Plan (RPJPN) and/or National Medium-term Development Plan (RPJMN) do not have the controlling procedures by the people. General Election can assess the level of president's obedience (their electability by the people) in carrying out the National Long-term Development Plan (RPJPN) or the National Medium-term Development Plan (RPJMN) showing the level of success or failure of the president (Setya Nugraha, 2019:207).

In addition, it also assesses that the National Long-term Development Plan (RPJPN) is made in the form of legal products (the laws) that will be easily revised like any other ordinary legislative processes (Holle, 2019:83-84). This will be different if the RPJPN is made at one level above the law which requires a specific mechanism as it was initially made in the form of People's Consultative Assembly's Decree.

The arrangement of the National Development Planning System (SPPN) was submitted to the President. The Law Number 25 of 2004 concerning the National Development Planning System (RPJPN) explained that the President should arrange the National Medium-term Development Plan
(RPJMN) consisting of vision and mission of the president which would be implemented for the next five years. This matter refers to the Preamble of 1945 Basic Constitution and the National Long-term Development Planning (RPJPN) which was ratified by the Law Number 17 of 2007 concerning the National Longterm Development Planning in 2005 to 2025 (Marwijah, Siti \& Nurwardani, 2014:90). The president who is newly inaugurated for running the government does not have the obligation to follow or continue the previous government programs. Thus, the National Long-term Development Planning occasionally seems inconsistent to be implemented by the current president. This issue is influenced by political power and the potentials of political constellation between the central and regional governments as the effects of direct election (Bahaudin, 2017:97-98).

Direct general elections are applied for both the president and regional heads whose process come from different political parties and individual basis. Political power at the national or regional level also influences the aims of the development. Meanwhile, the State of Indonesia needs the development planning either in the form of GBHN or the Medium-term Development Planning (RPJM) which is merely for the national interest and serves as a guideline for the rulers who keep being replaced based on the election results (Efriza, 2019:69-70). The weaknesses that arise are (as outlined above) that the development should be sustainable rather than simply continuing the previous president's plans. It must also concern the sustainability of the central government and the regional government. Structured and integrated development planning, as regulated in the National Development Planning System (SPPN), has certainly collected the development plans from the regional to the central level.

The implementation of National Development Planning System (SPPN) is the combination of National Long-term Development Planning (RPJPN) and National Medium-term Development Plan (RPJPM) made at the initial service period of the elected president. National Medium-term Development Plan (RPJMN) is dominated by executive proposals as the manifestation of vision and mission. On the other hand, Regional Medium-term Development Plan (RPJMD) is not in accordance with National Medium-term Development Plan (RPJMN) in terms of vision and mission after the succession of president 
and governors (Haryadi, 2018:2050-2051). The synchronization of planning and the involvement of every element of the state in the arrangement of development planning do not only focus on the executive's planning.

One of the Indonesian Democratic Party (of Struggle) (PDI-P) members named Ahmad Basarah states that there are weaknesses in the constitution of National Development Planning System (SPPN). First, the development plan focuses on executive power (Kanang, 2018:173). This type of development model removes the principles and spirit of mutual cooperation and promotes individualism, whereas, there are still legislatives and judicial powers that must be involved in the national planning. Second, there is an essential point in the Mediumterm Development Planning (RPJM) which is different, reduced, or more extended than what has been established in the Long-term Development Planning (RPJP).

In addition, there is no regulation in the Basic Constitution or other kinds of laws that prohibiting the reduction and extension of the plans. Third, there is the fact that the president and governors do not have the same vision, mission, and working programs. Therefore, there are some differences between the implementation of the National and Regional Medium-term Development Planning. Fourth, the successors of president and governors have no obligation to continue the currentlyrunning development programs, but those programs have not been completed by the previous President and Governors (https:// www.jawapos.com/ nasional/ politik/ 05/ 09/ 2019/ basarah-ungkap-empat-kelemahan uusppn/ accessed on Monday, October $21^{\text {st }} 2019$ 13.30 of West Indonesian Time). The view of the legislators above can be referred to as the correction towards the implementation of the National Development Planning System (SPPN) assessing that the system needs to be revised and improved. One of the improvements is through the existence of GBHN.

The GBHN regulation meant to be formed must be harmonized with the development planning system so that the provisions made can be implemented. The GBHN is made by People's Consultative Assembly; that is why the legal product is called People's Consultative Assembly's decree. If the People's Representative Council and the President determine the GBHN, the legal product is called Constitution/Law. The president has no authority to establish the GBHN since he is the executive power holder (Indra, Mexsasai \& Adhayanto, 2018:99). Arrangements regarding the GBHN are made in such a way that the evaluation of the National Development Planning System (SPPN) is no longer found when the GBHN is put into practice as the state direction in the future.

The society needs regulations because these regulations are in accordance with the interests of the society. Therefore, laws and regulations are made to meet their needs and interests (Wasti, 2015:82). The presence of the GBHN in the state administration can be the national guidelines which are integrated, directional and planned since it is the national collective document containing a long-term development strategy (Bahaudin, 2017:99). The GBHN should not be seen as the New Order product that must be avoided in the current reformation era. On the other hand, they are the dreams and ideas of Indonesian founding fathers outlined in the 1945 Basic Constitution (Bahaudin, 2017:91). In the New Order era, guidelines and direction of development intended to be achieved were set forth in the GBHN. Whereas, political, economic, legal, and cultural views can be collected in the form of the State's Direction (Susanto, 2017:431).

After the amendment of 1945 Basic Constitution, guidelines or directions for development were arranged based on the National Long-term Development Planning (RPJPN), the Medium-term Development Planning (RPJM), and the Government Work Plan (RKP) as regulated in the National Development Planning System (SPPN) Legislation. Therefore, the president/governor candidates have vision and mission that can be processed by the planning institution which will be transformed into the development planning document in line with the National Development Planning System (SPPN) Legislation. In terms of implementation period, National Long-term Development Planning (RPJPN) has a period of 20 years, Medium-term Development Planning (RPJM) has a period of 5 years, and Government Work Plan (RKP) has a period of 1 year (Sofia L.Rohi, 2013:83). The Basic Constitution mandates the National Development Planning System (SPPN) Legislation compiled by People's Representative Council together with the President to regulate the national development format and pattern (Anggraini et al., 2015: 81). The State Policy may 
comprise: first, the State Policy contained in the Basic Constitution; Second, the one contained in the People's Consultative Assembly's/Provisional People's Consultative Assembly's Decree; third, the one contained in the work program of People's Consultative Assembly's Decree concerning the GBHN; and fourth, the one contained in the National Budget Constitution (Asshiddiqie, 2010:18). The formulation managing the State Policy in the Basic Constitution must be in line and should not be in contradiction with the Basic Constitution itself. In addition, it can be implemented measurably during its implementation.

In the implementation of the National Long-term Development Planning (RPJPN), National Mid-term Development Planning (RPJMN), and Government Work Plan (RKP), there are several major problems need to be raised: first, the presidential program during the election tends to be populist, so that there are probably some obstacles when the program will be implemented; second, the presidential candidate's populist program tends to be short-term and not essential since it only highlights the surface, not the root of the problem; third, the society will only elect well-known presidential candidates and will not elect them based on their working programs; and fourth, presidential candidates are influenced by the political platforms of the supporting parties, which sometimes can be contradictory with the political will of the people (Sofia L.Rohi, 2013:89-90).

The above problems are among the reasons for bringing back the GBHN by taking into account the level of consistency between the previous president's development planning and the present one's.

There are some obstacles in implementing development planning such as: first, the difficulties to achieve the sustainability of the working program which are influenced by some political constellation. Second, the change of political configuration leads to the instability of the planning. The obstacles during the planning stage will affect the business world requiring the stability to build the investment atmosphere in Indonesia (Sofia L.Rohi, 2013:90). The appropriate and measurable planning will stimulate investment in Indonesia rather than the reversible and changeable planning according to the ruling regime. Therefore, the assumption of 'different president means different policies' can be avoided.

\section{Conclusions}

The discourse to bring back the GBHN is a constitutional step to arrange the GBHNbased national development planning system. However, the existence of the GBHN will bring some consequences towards the compulsory for the fifth 1945 Basic Constitution Amendment since the amendment will not take place without the authority to form the GBHN for People's Consultative Assembly that should be regulated in the Basic Constitution. There is a need to harmonize the established laws and regulations and prevent the absence of law in the context of legislation review since the Basic Constitution so far only regulates the mechanism of constitution review towards Basic Constitution. Meanwhile, there is no legal mechanism yet for People's Consultative Assembly's Decree. There is a need for the arrangement of president and vice president liability mechanism along with the changed position of People's Consultative Assembly towards President which is equal and balanced. In addition, there should be a re-arrangement of national development planning which is integrated from the central to regional levels, so that the aim of establishing the state purpose of Indonesian Republic can be accomplished as stated in the preamble of the 1945Basic Constitution.

\section{References}

Anggraini, Y., Yasir, A., \& Ridlwan, Z. (2015). Perbandingan Perencanaan Pembangunan Nasional Sebelum Dan Sesudah Amandemen Undang-Undang Dasar 1945. Fiat Justisia, 9(1), pp. 74-88. https://doi.org/10.25041/fiatjustisia. v9no1.589

Asmara, G. (2015). Penguatan Kelembagaan MPR dalam Sistem Ketatanegaran Negara Republik Indonesia. Hasanuddin Law Review, 1(3), pp. 357-370. https://doi. org/10.20956/halrev.v1n3.115

Asshiddiqie, J. (2010). Konsitusi dan Konstitusionalisme. Sinar Grafika.

Azwar, R. C. (2017). Demokrasi Indonesia: Suatu Pandangan Dialektis. Jurnal Ketatanegaraan, 2, pp. 1-36. https://doi. org/10.1017/CBO9781107415324.004

Bahaudin. (2017). Menghidupkan Kembali GBHN : Komparasi GBHN dan RPJPN sebagai Kebijakan Politik Hukum Nasional dalam Bidang Pembangunan. Jurnal Keamanan Nasional, 3(1), pp. 85-107. 
Efriza. (2019). Refleksi: Menghidupkan Kembali Eksistensi MPR dan GarisGaris Besar Haluan Negara (GBHN). Administratio, 10(2), pp. 59-70.

Faridhi, A. (2017). Penguji Peraturan Perundang-undangan Tunggal Keniscayaan. Mercatoria, 10(2), pp. 180-196.

Faridhi, A. (2018). Penggunaan Surat Keterangan dalam Pemilihan Kepala Daerah Kota Pekanbaru Tahun 2017. Jurnal Ilmiah Penegakan Hukum, 5(2), pp. 86-93.

Faridhi, A. (2019). Sengketa Pencalonan Pemilihan Kepala Daerah Kota Pekanbaru Tahun 2017. Pagaruyuang Law Journal, 2(2), pp. 239-256.

Fatmawati. (2004). Hak Menguji Indonesia. PT RajaGrafindo Persada.

Fauzan, M. (2011). Dalam Proses Impeachment Presiden Menurut Sistem Ketatanegaraan Republik Indonesia. Jurnal Dinamika Hukum, 11(1), pp. 71-86.

Firdaus. (2019). Refleksi Konstitusionalitas Pengawasan Peraturan Daerah Pasca Putusan Mahkamah Konstitusi Nomor 137 / PUU- XIII / 2015 Constitutionality Reflection of Local Constitutional Court Verdict Number 137/PUU-XIII/2015. Jurnal Konstitusi, 16(2), pp. 392-415.

Hajri, W. A., \& Rahdiansyah, R. \&. (2017). "Menghidupkan" Undang-Undang Dasar 1945 Tanpa Amandemen. Jurnal Hukum Ius Quia Iustum, 24(4), pp. 558-576. https://doi.org/10.20885/iustum.vol24. iss4.art3

Haryadi, D. (2018). Reformulasi Kewenangan Mpr Pasca Amandemen UUD NRI 1945. PROGRESIF: Jurnal Hukum, 12(1), pp. 2048-2055. https://doi.org/10.33019/ progresif.v12i1.956

Hendra. (2016). Pertanggungjawaban Politik Presiden Pasca Amandemen UUD 1945. Jurnal Wacana Politik, 1(1), pp. 9-21. https://doi.org/10.24198/jwp.v1i1.10544

Holle, E. S. (2019). Reformulasi Sistem Perencanaan Pembangunan Nasional Model Gbhn Sebagai Pelaksanaan Asas Kedaulatan Rakyat Dalam Rangka Perubahan Ke-V UUD 1945. Jurnal Hukum Volkgeist, 1 (1), pp. 73-85. https://doi. org/10.35326/volkgeist.v1i1.79

Hudi, M. (2018). Kedudukan dan Tanggungjawab Presiden dalam Sistem Presidensial di Indonesia. Mimbar Yustitia, 2(2), pp. 173-190. https://doi. org/10.1017/CBO9781107415324.004

Ilyas, M. (2013). Sistem Perubahan UUD Negara republik Indonesia Tahun 1945
(Suatu Kajian dalam Teori Perubahan Konstitusi). Jurnal Media Hukum FH Universitas Tompotika Luwuk, 1(1), pp.53-63.

Indra, Mexsasai \& Adhayanto, O. (2018). Politik Hukum: Reformulasi Garis-Garis Besar Haluan Negara (GBHN) dalam Sistem Ketatanegaraan Indonesia. Jurnal Ilmiah Hukum De'Jure:Kajian IImiah Hukum, 3(1), pp. 94-107. https://doi. org/10.1017/CBO9781107415324.004

Isra, S. (2013). Hubungan Presiden dan DPR. Jurnal Kontitusi, 10(3), pp. 399416. https://media.neliti.com/media/ publications/109222-ID-hubunganpresiden-dan-dpr.pdf

Kanang, A. R. (2018). Diskursus Pembatasan Kekuasaan Presiden Dalam Sistem Presidensial Menurut Uud 1945. Al Daulah: Jurnal Hukum Pidana Dan Ketatanegaraan, 7(1), pp.163-177. https://doi.org/10.24252/ad.v7i1.5902

Kristiyanto, E. N. (2013). Pemakzulan Presiden Republik Indonesia Pasca Amandemen UUD 1945. Jurnal RechtsVinding, 2(3), pp. 331-142. http://rechtsvinding.bphn. go.id/artikel/ART 2 JRV 3 NO 2 PROTECT. pdf

Kusumaningtyas, D. Y. P. (2018). Problematika Model Perencanaan Pembangunan Nasional Pasca-Amandemen UndangUndang Dasar Negara Republik Indonesia Tahun 1945. Jurnal Ummul Qura, XI(1), pp. $1-15$.

Marpaung, L. A. (2015). Analisis Yuridis Normatif Perbandingan Prosedur Pemberhentian Presiden Dalam Masa Jabatannya antara Indonesia dengan Amerika Serikat dan Korea Selatan. Pranata Hukum Jurnal IImu Hukum, 10(2), pp. 135-144.

Marwijah, Siti \& Nurwardani, N. (2014). Garis-Garis Besar Haluan Negara sebagai Penentu Arah dan Strategi Rencana Pembangunan Indonesia. Rechtidee Jurnal Hukum, 9(1), pp. 88-103.

Mulyani, T. (2016). Kajian Normatif Mengenai Hubungan Antar Lembaga Negara dalam Sistem Ketatanegaraan Republik Indonesia Berdasarkan Undang-Undang Dasar Tahun 1945: Sebelum dan Sesudah Amandemen. Jurnal Humani, 6(1), pp. 75-95. https:// webcache.googleusercontent.com/search ?q=cache:BDsuQOHoCi4J:https://media. neliti.com/media/publications/9138-IDperlindungan-hukum-terhadap-anak-darikonten-berbahaya-dalam-media-cetakdan-ele.pdf $+\& c d=3 \& h l=i d \& c t=c l n k \& g l=i d$

Nazriyah, R. (2017). Penguatan Peran Majelis 
Permusyawaratan Rakyat Dalam Struktur Ketatanegaraan Indonesia. Jurnal Hukum \& Pembangunan, 47(1), pp. 39-60. https://doi.org/10.21143/jhp.vol47. no1.134.

Rachmiatie, A., Ahmadi, D., \& Khotimah, E. (2015). Dinamika Transparansi Dan Budaya Badan Publik Pasca Reformasi Birokrasi. (Studi Kasus tentang Badan Publik se-Indonesia sebagai Badan Publik Perspektif UU Keterbukaan Informasi Publik No.14/2008 di Propinsi Jabar dan Kalbar). Sosiohumaniora, 17(3), 264. https://doi.org/10.24198/ sosiohumaniora.v17i3.8345.

Rendy. (2017). Menuntaskan Konsensus Lokal-Nasional (yang) Berkelanjutan: (Membaca Ulang rasionalisasi dan Idealisasi Pembangunan Model GBHN). Jurnal Society, 5(1), pp. 23-31.

Ridlwan, Z. (2012). Negara Hukum Indonesia Kebalikan Nachtwachterstaat. Fiat Justitia Jurnal Ilmu Hukum, 5(2), pp. 141-152.

Rohmat, A. M. (2016). Kedudukan Dan Kewenangan Majelis Permusyawaratan Rakyat Dalam Era Reformasi. Jurnal Pembaharuan Hukum, 3(2), pp. 181-190. https://doi.org/10.26532/jph.v3i2.1408

Saraswati, P. S. (2017). Pemberlakuan Kembali Garis Besar Haluan Negara (GBHN) Dalam Undang-Undang Dasar. Seminar Nasional Fakultas Hukum Universitas Mahasaraswati Denpasar, pp. 235-243.

Sekretariat Jenderal MPR. (2017). Panduan Pemasyarakatan Undang-Undang Dasar Negara Republik Indonesia Tahun 1945 dan Ketetapan Majelis Permusyawaratan Rakyat Republik Indonesia (Cetakkan K). Sekretariat Jenderal MPR RI.

Setiadi, A. (2016). Cakrawala Hukum Cakrawala Hukum. Cakrawala Hukum, XII(1), pp. 95-110. https://doi.org/34/32/10701 [pii] \r10.1523/JNEUROSCI.0832-14.2014 [doi]

Setya Nugraha, H. (2019). MPR dan Urgensi Garis Besar Haluan Negara dalam Sistem Ketatanegaraan Indonesia. Veritas et Justitia, 5(1), pp. 191-217. https://doi. org/10.25123/vej.3293

Simamora, J. (2014). Tafsir Makan Negara Hukum Dalam Prespektif Undang-Undang Dasar Negara Republik Indonesia Tahun 1945. Jurnal Dinamika Hukum, 14(3), pp. 547-561.

Simamora, J. (2016). Urgensi Keberadaan
GBHN Dalam Sistem Ketatanegaraan Republik Indonesia. Litigasi, 17(2), pp. 3427-3466. https://doi.org/10.23969/ litigasi.v17i2.143

Simatupang, T. H. (2019). Mendudukkan Konsep Executive Review dalam Sistem Hukum Ketatabegaraan Indonesia. Jurnal Penelitian Hukum De Jure, 19(2), pp.217230.

Sofia L.Rohi. (2013). Implikasi Amandemen Undang-Undang Dasar 1945 Terhadap Sistem Perencanaan Pembangunan Nasional. Jurnal Politica, 4(1), pp. 82-92. https://doi.org/10.14710/ politika.4.2.2013.82-92

Subkhan, I. (2014). GBHN dan Perubahan Perencanaan Pembangunan di Indonesia. Aspirasi, 5(2), pp. 131-143.

Sukma, N. M. (2017). Sinkronisasi Reformulasi Sistem Perencanaan Pembangunan nasional Model GBHN dengan Sistem Presidensial. Jurnal IImiah Galuh Justisi, 5(2), pp. 278-290.

Sunarto, S. (2016). Prinsip Checks and Balances Dalam Sistem Ketatanegaraan Indonesia. Masalah-Masalah Hukum, 45(2), pp. 157-163. https://doi. org/10.14710/mmh.45.2.2016.157-163

Susanto, M. (2017). Wacana Menghidupkan Kembali GBHN dalam Sistem Presidensil Indonesia. Jurnal Penelitian Hukum De Jure, 17(3), pp. 427-445. https://doi. org/10.30641/dejure.2017.v17.427-445

Wasti, R. M. (2015). Pengaruh Konfigurasi Politik Terhadap Produk Hukum Pada Masa Pemerintahan Soeharto Di Indonesia. Jurnal Hukum \& Pembangunan, 45(1), pp. 76-105. https://doi.org/10.21143/ jhp.vol45.no1.10

Wheare, K. . (1996). Konstitusi-Konstitusi Modern (N. Mangunsong (ed.); 5th ed.). Nusa Media.

Yusdar. (2016). Format Kelembagaan dan Pola Hubungan MPR Dengan DPR dan DPD Pasca Amandemen UUD Tahun 1945. Jurisprudentie, 3(2), pp. 161-172.

Zoelva, H. (2011). Pemakzulan Presiden di Indonesia. Sinar Grafika.

Zulfan. (2017). Pemisahan Kekuasaan Hubungan Presiden Dan Dewan Perwakilan Daerah Dalam Fungsi Legislasi. Masalah-Masalah Hukum, 46(2), pp. 146-154. https://doi.org/10.14710/ mmh.46.2.2017.146-154. 